\title{
Black Sea Container Market and Georgia's Positioning
}

\author{
Irakli Danelia, (PhD student) \\ Tbilisi State University, Georgia
}

Doi:10.19044/esj.2018.v14n31p100 URL:http://dx.doi.org/10.19044/esj.2018.v14n31p100

\begin{abstract}
Due to the strategically important geographical location, Black Sea region has a key transit function throughout between Europe and Asia. Georgia, which is a part of Black sea area, has a vital transit function for Caucasus Region, as well as for whole New Silk Road area. Nevertheless, still there is no evidence what kind of role and place Georgia has in The Black Sea container market.

As the country has ambition to be transit hub for containerizes cargo flows between west and east and is actively involved in the process of formation "One Belt One Road" project, it is very important to identify Country's current circumstances, capacities and future potential. Because of this, the purpose of the study is to investigate cargo flows and opportunities of the Black Sea container market, level of competitiveness in the area and define Georgia's positioning in the regional Container market.
\end{abstract}

Keywords: Geostrategic Location, New Silk Road, Transit Corridor, Cargo flow, Container market, Georgia, Black Sea

\section{Methodology}

Based on practical and theoretical significance of the research the following paper provides systemic, historical and logical generalization methods of research in the performance of the work, scientific abstraction, analysis and synthesis methods are also used.

\section{Introduction}

Since the end of the Cold War, the Black Sea region has no longer been a static border between the West and the East. The region's geostrategic location, proximity to the Eurasian energy corridor, as well as the transformation process to democracy and good governance, are some of the factors which make the region a priority for international actors. The collapse of the Soviet Union drastically increased the number of independent players 
around and brought new political, economic, and social forces to the region. The Black Sea basin is a strategically important area serves as a pivotal EastWest and North-South corridor and a crossroad of geopolitics, economic, energy and culture. It is a very dynamic region that presents various challenges and offers many opportunities. Black sea container market is represented by Ukraine, Romania, Russia (Black Sea part), Bulgaria and Georgia. Since Georgia's transit potential is interconnected with the geopolitical and geoeconomic functions on regional and international levels, all supposed economic and political risks, challenges and opportunities should be profoundly analyzed (Danelia I., 2016) Georgia has an ambition to become a transit hub not only for Caucasus region, but also for whole West and East cargo flows coming from China going to West European counties, But the country's positioning among the rest of member states on the black sea container market is still not evidence.

The paper is organized as follows: the first part gives theoretical overview regarding The Black Sea region's economic circumstance since 1989 year On the crossroads between Europe and Asia, Russia and the Middle East and formulates research question. The second part is devoted to the Black Sea Container market overview in figures since 2000 years till $1 Q$ of 2018. Its reflects currect trends and infrastructural facilities for existed cargo flows in the region. The third part describes Georgia's role and opportunity in development of Black Sea Container market, There is identified Poti, Batumi and Anaklia sea ports facilities and potencials as well. The fourth part gives research results. The main findings and recommendation are presented in the conclusive part of the paper.

\section{The Black Sea region - Economic Outlook}

On the crossroads between Europe and Asia, Russia and the Middle East, the black sea region is not only an area of geo-strategic and geo-political importance, it combines many different nations (Bulgaria, Romania, Ukraine, Russia, Georgia, Armenia, Azerbaijan, and Turkey), cultures and ethnical groups. For about a decade after 1989, the Black Sea area largely remained outside the reform and integration agenda of the European project. Today, the Black Sea region is reemerging from the periphery and establishing itself as a part of the European project. Owing to the dynamic expansion of their demand, the countries in the region offer a considerable market potential for EU, China as well as USA. 
As various initiatives and strategies (e.g., "Eastern partnership"10, Association Agreement with Georgia, Ukraine and Moldova, DCFTA ${ }^{11}$ with Georgia etc) show the EU has aimed at deepening its relations with the Black Sea region for several years.

Besides the location at the crossroads of Europe, Central Asia and the Middle East the Black Sea region's market potential and labor pool offer economic opportunities. An additional dimension of the potentially conflicting interests in the region is its importance as a transit corridor for the energy resources from the Caspian Basin to Europe. Recent EU efforts to diversify energy supplies — in particular to reduce the EU's dependence on Russia, which is now not only a major supplier of natural gas to Europe, but also controls a bulk of transit from the Caspian energy-rich countries (notably Kazakhstan and Turkmenistan), explain the rising interest in the Black Sea region and the resulting rivalry between the EU and Russia (Rudolf G. Egging and Steven A. Gabriel, 2006).

The Black Sea area can be called a heterogeneous economic area. The economies differ in several aspects with the exception of Turkey, they all emerged from the USSR and went through a lengthy and profound transformation process, which, in part, is still ongoing. The initial situation in the 1990s differed widely, particularly in terms of the decline in industrial production and the per capita income after independence (Ederer S. \& Sieber S., 2018) However, more recently, the region has enjoyed a fairly rapid economic recovery accompanied by welcome structural changes, although the labor market situation and social conditions in general are still very difficult (Astrov V., \& Havlik P., 2008).

The Macroeconomic conditions for the Black Sea countries are mostly positive, with annual GDP growth in excess of 5\% in the medium and long run being feasible. Apart from sound economic policies, it is especially the fostering of institutional reforms and the related improvements of the investment climate which will be crucial for sustainable economic development.

${ }^{10}$ The Eastern Partnership (EaP) is a joint initiative involving the EU, its Member States and six Eastern European Partners: Armenia, Azerbaijan, Belarus, Georgia, the Republic of Moldova and Ukraine.

11 The Deep and Comprehensive Free Trade Areas (DCFTA) are three free trade areas established between the European Union, and Georgia, Moldova and Ukraine respectively. The DCFTAs are part of each country's EU Association Agreement. They allow Georgia, Moldova and Ukraine access to the European Single Market in selected sectors and grant EU investors in those sectors the same regulatory environment in the associated country as in the EU. 


\section{Black Sea Container market overview}

Black sea container market is represented by Ukraine, Romania, Russia (Black Sea part), Bulgaria and Georgia. In Q1 2018 it had a volume of 732948 TEU. In Q1 2017 Russia and Ukraine had major shares of the market approx. $-28 \%$ and $26 \%$ respectively, while Romania had almost $24 \%$ share, Georgia belongs roughly $14 \%$ and Bulgaria - 8\%. In Q1 2018 the situation remained the same - Russia had a major share of $30,57 \%$, while Ukraine secured the second place with $26,67 \%$ and Romania remained third with $21,20 \%$ share, Georgia has decreased its share to $13,60 \%$, while Bulgaria decreased to $7,97 \%$.

Fig. 1 Black Sea region terminals

(Constanta, Odessa, CTI, Yuzhny, Novorossiysk, Varna, Burgas, Poti, Batumi), TEU

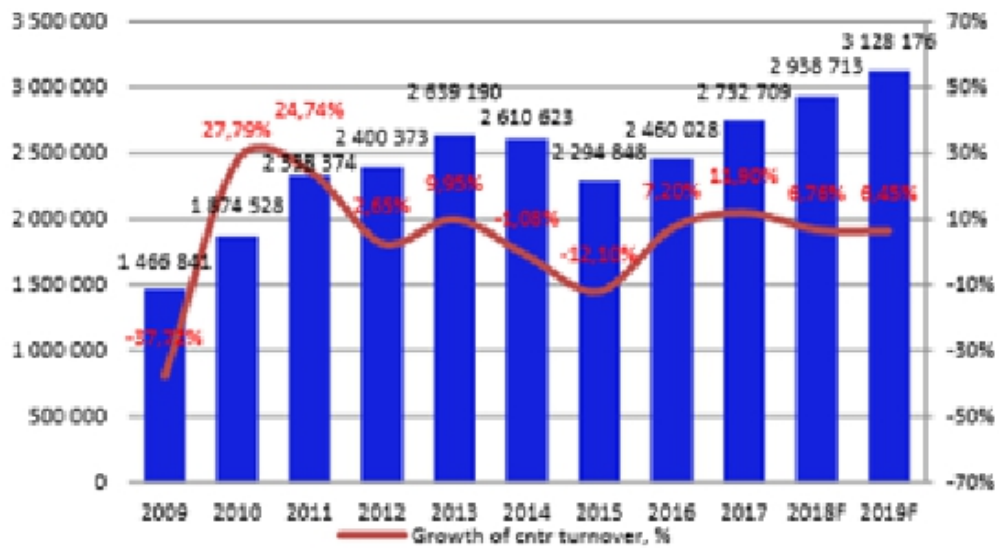

Source: Diagram is formed by Author based on Black Sea Countries' official Statistical databases (Ports/terminals operators)

As for container terminals of the region, the most significant growth was reached by following terminals: NUTEP (Russia), BKP (Ukraine), NLE (Russia) and TIS (Ukraine). In 2017-2018 DPW (Romania) remained at the first place by total container turnover, Russian NUTEP (Novorossiysk) secured second place. The APMT POTI terminal (Georgia) took third position. The world financial crisis touched the Black Sea in 2008 with the fall of volumes in 2009 (Shelest H., \& Kapitonenko M., 2015) During 2010-2011, while the Black Sea market was recovering after the crisis in 2010-2011, growth rates were at the level of $26 \%$ and slowed down in 2012-2013. In 2012 market growth was $2,65 \%$ with a further growth of $9,95 \%$ in 2013 . However, in 2014 another crisis took place ${ }^{12}$ and caused a 1,08\% drop of the Black Sea container

12 In February 2014, Russia made several military incursions into Ukrainian territory. After Euromaidan protests and the fall of Ukrainian president Viktor Yanukovych, Russian soldiers without insignias took control of strategic positions and infrastructure within the Ukrainian territory of Crimea. Russia then annexed Crimea after a referendum in which Crimeans allegedly voted to join the Russian Federation, according to official results. 
market with a further drop of $12,10 \%$ in 2015 . In 2016 the market has grown by $7,20 \%$ followed by $11,90 \%$ growth in 2017 .

In spite of the lack of capacity and high freight rates Russia showed growth of volumes in 2013, but in 2014 there was a small drop of $0,33 \%$ with a further drop of $18,93 \%$ in 2015 compared to 2014. In Ukraine slowdown in growth rates in 2011-2012 was caused by changes in customs clearance procedures, while ports lost by different evaluations from 50 to 100 thousands of TEU in favor of North European main ports (Hamburg, Rotterdam, Antwerp), Baltic ports and even Romania. The Ukrainian economy was stagnating and political crisis which started in December 2013 had a negative influence on the economy, especially on container market. Thus, there was a $22 \%$ fall of container turnover in 2015 compared to 2014. In 2017 all countries of the region have shown an increase of container turnover. In 2017 Romania achieved growth of $6,42 \%$. In 2015 Ukraine had the highest drop rate of $22,12 \%$, which was a result of the military conflict in the eastern part of the country, but in 2016 compared to 2015 Ukraine achieved unexpected increase of $31 \%$ which was a positive impulse for the market, however, in 2017 Ukrainian container turnover has grown by 6,38\% only. Bulgaria achieved $9,79 \%$ growth in 2017 compared to 2016. Russia achieved growth of approx. $5 \%$ in 2016 against 2015. A military conflict in the East of Ukraine and extended western economic sanctions against Russia definitely had an impact on container turnover of the port of Novorossiysk. However, in 2017 the economic situation in Russia was stabilized and container growth continued $20 \%$ in 2017 against 2016.

According to the World bank - the average GDP growth of the Black Sea countries after the crisis was at the level of 3,58\%. In 2015 the average GDP of the Black Sea region was estimated at $-0,44 \%$. Since 2009 average container growth per $1 \%$ GDP growth was 4,72\%. However, the average GDP of the Black Sea region in 2015 was estimated at $-0,44 \%$, while total container turnover decreased by $12,10 \%$. In 2016 this ratio was estimated at 1,52 and the total container turnover increased by 7,2\%. In 2017 the ratio was estimated at 3,27 and the total container turnover increased by $11,90 \%$. There is expected a market increase of $186 \mathrm{k}$ TEU and the Black Sea market should reach roughly $3 \mathrm{M}$ TEU till the end of 2018.

Fig. 2 GDP Growth - Data and Forecast, \%

\begin{tabular}{|c|c|c|c|c|c|c|c|}
\hline & $\mathbf{1 0}-\mathbf{1 3}$ & $\mathbf{1 4}$ & $\mathbf{1 5}$ & $\mathbf{1 6}$ & $\mathbf{1 7}$ & $\mathbf{1 8}$ & $\mathbf{1 9}$ \\
\hline Bulgaria & 1,75 & 1,3 & 3,6 & 3,9 & 3,8 & 3,9 & 4,0 \\
\hline Georgia & 4,9 & 4,6 & 2,9 & 2,8 & 4,3 & 4,2 & 4,7 \\
\hline Romania & 2,75 & 3,1 & 3,9 & 4,8 & 6,4 & 4,5 & 4,1 \\
\hline Russian Federation & 2,65 & 0,7 & $-2,8$ & $-0,2$ & 1,7 & 1,7 & 1,8 \\
\hline Ukraine & 1,6 & $-6,6$ & $-9,8$ & 2,3 & 2,0 & 3,5 & 4,0 \\
\hline
\end{tabular}

Source: The World Bank Data - https://www.worldbank.org 
Georgia as an important contributor of Black Sea Container market

Georgia is situated in a strategic location on the "One Belt One Road" route, positioned along the shortest route between China and Europe, acting as a gateway for cargo to enter the landlocked Central Asian and Caucasian regions. The realization and development of Georgia's transport potential began in the 90 s of the 20th century and is still one of the important components of the country's economy. Georgia is key part of the Europe-Caucasus-Asia transport corridor (Danelia I., 2017). Besides, the country is a member of Black sea container market as well.

Numerous theoretical research based on the model of gravity confirms that trade between geographically close countries is favorable if other essential factors will not be a hindrance (See, for example. The research carried out on the Georgian export of Papachashvili et al., 2018). This circumstance give us stimulus to study the transit potential of the Black Sea countries and develop practical recommendations.

In addition, while analyzing bilateral economic relations, researchers indicate that trading-economic potential is not appropriately used (See, for example Papachashvili et al., 2017).

Georgian container market is represented by terminals in Poti and Batumi. Those Ports unlocks a primary market (Georgia, Azerbaijan, Armenia) of 18 million people from the Caucasus region and another 145 million people from landlocked/Hartland ${ }^{13}$ countries in Central Asia (Kazakhstan, Uzbekistan, Turkmenistan, Kyrgyzstan and Tajikistan). The terminal in Poti is operated by APMT, and terminal in Batumi by ICTSI. Georgia had 13,60\% share at the Black Sea market and reached 99674 TEU in Q1 2018. There was a significant volume growth of $13 \%$ in Q1 2018 compared to Q1 2017. Georgia has lost 0,13 p.p. of share.

Poti Sea Port holds an important place in global containerization, particularly in TRACECA Project. For the above, such container shipping lines as MAERSK, MSC, CMA CGM, EMC, ZIM, HAPAG LLOYD and others have become well established in Poti Port. The above companies engage in containerized shipments not only to and from the countries of the Caucasus but Central Asian countries as well. Port is owned by global terminal operator APM Terminals. The berth as such is a hydro technical facility of $210 \mathrm{~m}$ in length and $8.5 \mathrm{~m}$ in depth. In addition Poti sea port launched a multifunctional container terminal with $250 \mathrm{~m}$ length and $8.5 \mathrm{~m}$ depth. The terminal's present

\footnotetext{
13 The Geographical Pivot of History" is an article submitted by Halford John Mackinder in 1904 to the Royal Geographical Society that advances his heartland theory. The Heartland lay at the center of the world island, stretching from the Volga to the Yangtze and from the Himalayas to the Arctic. Mackinder's Heartland was the area then ruled by the Russian Empire and after that by the Soviet Union, minus the Kamchatka Peninsula region, which is located in the easternmost part of Russia, near the Aleutian Islands and Kurile islands.
} 
capacity is 400000 TEU annually and due to strong demand, the further development plans are on the way (For more details visit http://www.apmterminalspoti.com/index.php/en)

Batumi Sea Port efficiency is 100000 TEU annually, there are 5 terminals and 11 berths + CBM (point without berthing loading). The total throughput of the Port is 18 million tons per year. The number of ships of the port fleet totals 13 units (For more details visit https://www.batumiport.com)

Fig. 3 Georgian Maritime Capacity Market share and Capacity - Poti VS Batumi

\begin{tabular}{|c|c|c|c|c|}
\hline Terminal & $\begin{array}{c}\text { Annual capacity, } \\
\text { TEU }\end{array}$ & $\begin{array}{c}\text { Projected capacity, } \\
\text { TEU }\end{array}$ & TOP-5 major customers & Market share \\
\hline APMT POTI & 400000 & 650000 & $\begin{array}{l}\text { MAERSK, MSC, } \\
\text { EVERGREEN, COSCO, } \\
\text { CMA CGM }\end{array}$ & $82,31 \%$ \\
\hline ICTSI BATUMI & 100000 & 100000 & MSC & $17,69 \%$ \\
\hline TOTAL & 500000 & 750000 & & $100,00 \%$ \\
\hline
\end{tabular}
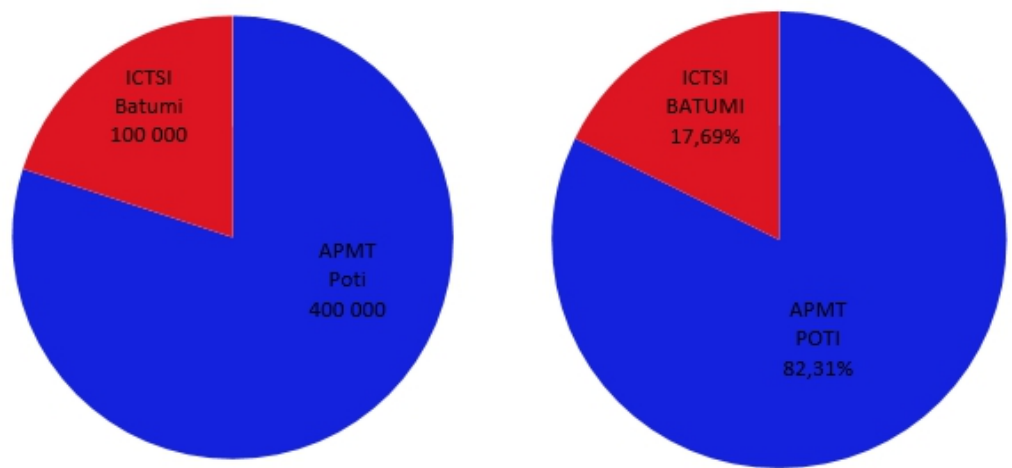

Source: Formed by Author based on APMT POTI \& ICTSIBATUMI

Poti and Batumi ports takes part in many transport projects and corridors, being a participant of the Trans-Caspian International Transport Route TITR, the Eurasian transport corridor TRACECA and the Association of ports of the Black and Azov Seas BASPA.

Beside above-mentioned sea ports, Georgia is making great hope on Anaklia Deep-sea port, the first deepwater container port in Georgia, is being developed by Anaklia Development Consortium (ADC). The new port will enhance Georgia's port infrastructure while reducing the cost of trading and improving economic opportunities regionally and domestically. World-class port complex will be a vital point of trade to and from Central Asia, as well as to serve the New Silk Road trade between China and Europe (Danelia I., 2016)

Ground-breaking ceremony of the new Deep-sea port was held in December 2017 and first phase of the project is scheduled for completion in 2021. The Deep-sea port is being developed on 340ha of land at Anaklia on the Black Sea coast of Georgia. The port will have the capacity to handle 100 
million tons $(\mathrm{Mt})$ of container. It will have a depth of $16 \mathrm{~m}$, which allows for berthing vessels with the capacity of up to 10,000 twenty-foot equivalent units (TEUs). SSA Marine will be the operator of the new container terminal at the Anaklia Deep-sea port. The Anaklia Deep-sea port will be developed in nine phases, with a total investment of $\$ 2.5 \mathrm{bn}$ (For more details visit http://anakliadevelopment.com)

APMT Poti was on the third place among all container terminals at the Black Sea and it achieved volume growth of 15,06\%, reached 82039 TEU in Q1 2018 or $11,19 \%$ share at the Black Sea. The Batumi terminal has a tiny share of 2,41\%, it handled 17635 TEU in Q1 2018, the terminal achieved $4,28 \%$ growth of volume and lost 0,23 p.p. of share at the Black Sea market in Q1 2018.

Georgia showed a slowdown of growth rates in 2012 for the account of ceasing local investments due to government change, but this trend changed in 2013. In 2014 transit through Georgia had grown and partly compensated the decrease in Georgian domestic market.

In 2015 Georgia faced 15,03\% decrease of container turnover. In 2016 the decrease of Georgian container turnover slowed down, but there was a drop of $13,27 \%$ compared to 2015 . It can be explained by the crisis, which came to Georgia later than it took place in Ukraine and Russia. Transit traffic through Georgia to Azerbaijan has significantly decreased due to a strong decline of the local currency. Despite that, in 2017 Georgia achieved significant growth of $19,84 \%$.

Fig. 4 Georgia (Poti, Batumi Terminals), TEU

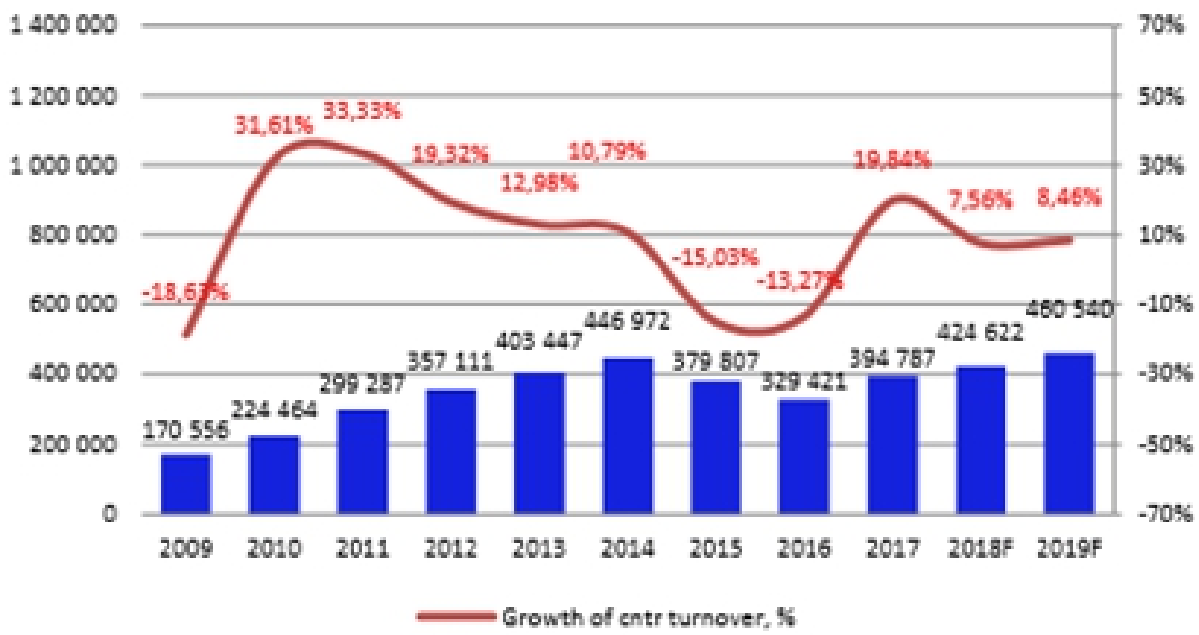

Source: The Ministry of Economy and Sustainable Development of Georgia www.economy.gov.ge

In 2014 container turnover growth of Georgian terminals decreased compared to 2013, but the military conflict in the East of Ukraine had a positive 
impact on it. Thus, transit cargo traffic to/from Kazakhstan and Russia, which was handled by Ukrainian terminals, had to bypass the military conflict zone and it was reoriented to Georgian ports and terminals. On the other hand, continued economic sanctions against Russia affected economic activity of Kazakhstan and Azerbaijan. For example, due to the drop down of oil price the economy of Azerbaijan declined (The Center for Economic and Social Development-CESD, 2014) and it has affected Georgian container traffic in transit to Azerbaijan. At the same time, the economic crisis in Georgia deepened and resulted in an overall decrease in cargo transportation volume. According to the World bank, the GDP growth of Georgia in 2017 was estimated at 4,3\%. However, in 2017 Georgian economy started to revive step by step and total container throughput has grown by almost $20 \%$ after two consecutive years of decline. Thus, Georgian container market is expected to increase by $8 \%$ and its annual volume is foreseen as about $425 \mathrm{k}$ TEU.

In order to evaluate Georgia's opportunities to have great positioning in the Black Sea market there should be considered Logistic Performance Index ${ }^{14}$ which is an interactive benchmarking tool created to help countries identify the challenges and opportunities they face in their performance on trade logistics and what they can do to improve their performance. Based on 2018-year Georgia is on 124 stage on a ranking out of 167 states. Currently, The country got 2.36 score out of 5.0 in Infrastructural bases, Customs Procedure and International Shipments have the same - 0.38 score, there are a bit less scores for Logistic competence, Tracking \& Tracing and for Timeliness -2.27 and 2.37 score.

Georgian import/export structure is most imbalanced, there was $49,92 \%$ of full import and only $7,79 \%$ of full export, $42,05 \%$ is empty export. Full export share decreased by 2,89 p.p. in Q1 2018 compared to Q1 2017, while full import share increased by 0,45 p.p. As per Geostat, most of the Georgian import comes from Far East and South East Asia - about 45\%, Mediterranean - about 19\%, Europe - about 18\%, North and South America about $9 \%$.

Most of the Georgian export goes to Far East and South East Asia about 32\%, Mediterranean - about 20\%, North and South America - about $16 \%$, Arabian Gulf and Red sea - about 11\%, Europe - about $10 \%$ and Indian Subcontinent - about $9 \%$. In terms of Georgian export, the main commodities are wine, mineral water and juices, fertilizers and scrap metals. Import consists of building materials, used cars, ceramic tiles, furniture and textile.

It is noteworthy that the global changes caused by informational revolution as a means of activating trade-economic relations and thus

${ }^{14}$ The LPI is an interactive benchmarking tool created to help countries identify the challenges and opportunities they face in their performance on trade logistics and what they can do to improve their performance https://lpi.worldbank.org 
emergence of new challenges in the market of containerized transportation, Also in terms of emergence of new opportunities for regulating traffic movement (Papachashvili N., 2018). More possibilities are made for institutional compatibility, which affects trade-economic relationships between partner countries (Jamagidze L., 2018)

\section{Conclusion}

On the basis of the analysis we have concluded that the Black Sea container market development depends on member countries' Political, Macroeconomic and technical facilities, but also cargo flows on West-East transit corridor as well. Moreover, in order to increase cargo flows in container's volume on the black sea market there is no enough to focus only transit goods coming from central Asian countries and China to EU, but also there is necessary to stimulate internal trade intensity. In order to facilitate trade relations among the region's counties there should be commonly agreed tariff policy, communized customs procedures and common rules of cargo transportation.

Georgia's positioning on the Black sea market is prosperous with potential to increase based on various factors. As the country's total volume goes to transit cargo it's very crucial to take into consideration that Georgia can increase its cargo turnover if Azerbaijan, Armenia and Asian landlocked countries will increase their external trade activities. Nevertheless, one of the most important subject is the common economic factor. From the above factor, the following major determinants identified: the level of infrastructures, the level of transport policy among neighboring states and macroeconomic growth rates in trading partner states. Under the new Silk Road, it is of great importance that the countries involved in this transit corridor have a growing tendency of trade among each other. It is important to have a balanced political relationship with all the forces interested in Georgia's transit function. Logistics Performance Index proposed by the World Bank is an important determinant to strengthen Georgia's positioning in the black sea container market. The Analysis reveals the impulses that improvement of determinants such as: customs operations and border procedures; Logistics infrastructure; monitoring and controls of cargo turnover will be a vital for further development of the Black Sea container market.

\section{References:}

1. Astrov V. and Havlik P., 2008, Economic Developments in the Wider Black Sea Region 
2. CESD Press, Baku, Azerbaijan, 2014, Assessment of Effect of Declining Oil Prices on Azerbaijan Economy - The Center for Economic and Social Development (CESD) http://cesd.az/new/?tag=effect-of-declining-oil-prices-on-azerbaijanbank-sector

3. Danelia I., 2017, "Main Determinants of Georgia's Transit Function Development". https://eujournal.org/index.php/esj/article/view/10207

4. Danelia I., 2016, "Peculiarities of Georgia's Transit Role and Current Challenges"

$\mathrm{http} / / / \mathrm{cbw}$.ge/economy/peculiarities-of-georgias-transit-role-andcurrent-challenges/

5. Danelia I., 2016, "Anaklia Port and its Prospect". http://forbes.ge/news/1309/anakliis-porti-da-misi-perspeqtivebi

6. Ederer S., Sieber S., 2011, The Black Sea Region - Economic Trends and Role for Austria's External Sector

7. Hamilton, Daniel and Mangott, Gerhard (eds.), 2008, The Wider Black Sea Region in the 21st Century: Strategic, Economic and Energy Perspectives (Washington, D.C.: Center for Transatlantic Relations)

8. Jamagidze L., 2018, The Role of Cultural and Institutional Differences in Georgia-EU Economic Relations, International Conference: Bringing the strands together: new prospects for the social sciences? Multiple challenges in the Southern Caucasus and The Broader Regional Context, 18-19 November 2016, Tbilisi, Georgia

9. Kakachia K., 2012, Reinvegorating Cross Border Cooperation In Black Sea Region: Visions for Future (ed.) GEORGIAN INSTITUTE OF POLITICS

10. Kuo L., Kommenda N., Jul. 30, 2018, What is China's Belt and Road Initiative?

https://www.theguardian.com/cities/ng-interactive/2018/jul/30/whatchina-belt-road-initiative-silk-road-explainer

11. Papachashvili N., 2018, Industry 4.0 and its Impact on the International Trade, Стратегічні імперативи сучасного менеджменту : зб.матеріалів IV Міжнар. наук.-практ. Конф,19-20 квітня, КНЕУ, 2018, pp. 444-453 http://ir.kneu.edu.ua/bitstream/2010/24417/1/5348.pdf

12. Papachashvili N., Jamagidze L., Melitauri N., 2018, The Analysis of Export Drivers and Impediments Using Extended Gravity Model (The Case of Georgia), Economic Alternatives, 2018, Issue 1, pp. 69-85 https://www.unwe.bg/eajournal/en/journalissues/list/99

13. Papachashvili N., Zhelev P., Jamagidze L., 2017, Economic Relations between Georgia and Bulgaria: Current State and Prospects. 
Ekonomisti. Tb.: Ivane Javakhishvili Tbilisi State University Paata Gugushvili Institute of Economics, 2017, \#4, volume XIII, pp.110-129. http://www.pgie.tsu.ge/contentimage/sxvadasxva/jurnali_ekonomisti/ 4-2017_.pdf

14. Rudolf G. Egging and Steven A. Gabriel, 2006, Examining Power in the European natural gas market," in Energy Policy

15. Shah S., March 5, 2018, Georgia Makes Waves With Anaklia DeepSea Port https://emerging-europe.com/intelligence/georgia-makeswaves-anaklia-deep-sea-port/

16. Shelest H. and Kapitonenko M., 2015, LIVING IN SUSTAINED UNCERTAINTY. THE BLACK SEA REGION AFTER THE 2008 GLOBAL FINANCIAL CRISIS http://fes.kiev.ua/n/cms/fileadmin/upload2/uaa2015-2.pdf

17. Shelest H. and Kapitonenko M., Ukraine Analytica - Issue 2 (2), 2015, The Change of Security Paradigm http://library.fes.de/pdf-files/bueros/ukraine/12961/2015-1.pdf

18. Tweed D., August 23, 2018, China's New Silk Road https://www.bloomberg.com/quicktake/china-s-silk-road

19. Yuhas A., 2014, Ukraine crisis: an essential guide to everything that's happened so far https://www.theguardian.com/world/2014/apr/11/ukraine-russiacrimea-sanctions-us-eu-guide-explainer

20. http://anakliadevelopment.com

21. http://geostat.ge

22. http://www.apmterminalspoti.com/index.php/en

23. http://www.dcfta.gov.ge

24. http://www.economy.gov.ge

25. http://www.worldbank.org

26. https://lpi.worldbank.org

27. https://www.batumiport.com 